\title{
The Use of Negative Pressure Therapy for the Treatment of the Defects on Extremities due to High-Energy Trauma
}

\author{
Yüksek Eneriili Travma Nedeni ile Oluşmuş Ekstremite Defektlerinin Tedavisinde \\ Negatif Basınçlı Terapi Kullanılması \\ - Erkan Orhan, ๑ Bülent Erdoğan* \\ Namık Kemal University Faculty of Medicine, Department of Plastic Surgery, Tekirdağ, Turkey \\ *University of Health Sciences, Ankara Numune Training and Research Hospital, Clinic of Plastic Surgery, Ankara, Turkey
}

Abstract

\begin{abstract}
Aim: Defects of the extremities due to high-energy trauma are common and it is necessary to repair these defects. Reconstruction is possible with simple surgeries using skin grafts and negative pressure therapy (NPT). In this study, we present our results of the reconstruction of extremity defects caused by high-energy trauma with a simple surgical procedure using NPT.
\end{abstract}

Methods: Patients with soft tissue defects of the upper and lower extremities caused by high energy trauma, who were treated with NPT between November 2009 and June 2015, were included in the study.

Results: NPT was performed in 63 patients. The average defect size was $60 \mathrm{~cm}^{2}$. The patients underwent an average of nine sessions. The average length of hospital stay was 26 days. The defects were reconstructed using skin grafts and local flaps in 58 and two patients, respectively. None of the patients required free flaps.

Conclusion: Extremity defects occurring due to high energy trauma can be closed by simple surgical techniques using NPT, patients can be protected from the complications of free tissue transfer, and also treatment is possible at much lower costs.

Keywords: Wounds, negative pressure therapy, extremity, trauma
Öz

Amaç: Ekstremitelerde yüksek enerjili travmalar sonucu defekt oluşması sık görülmektedir ve bu defektlerin onarılması zorunludur. Negatif basınçlı terapi (NBT) kullanılarak bu defektlerin deri greftleri gibi daha basit cerrahi işlemler ile rekonstrüksiyonu mümkün olabilmektedir. Bu çalışmada yüksek enerjili travma sonrası ekstremitelerinde oluşmuş defektlerin NBT kullanılarak basit cerrahi işlemlerle kapatıması konusundaki sonuçlarımızı sunmaktayız.

Yöntemler: Kasım 2009-Haziran 2015 yılları arasında üst ve alt ekstremitelerinde yüksek enerjili travma sonucu yumuşak doku defekti oluşan ve tedavisinde NBT kullanılan hastalar çalışmaya alındı.

Bulgular: Altmış üç hastada NBT uygulandı. Hastalardaki yara alanı ortalaması $60 \mathrm{~cm}^{2}$ olarak hesaplandı. Hastalara ortalama dokuz seans NBT uygulandı ve ortalama 26 gün yatarak tedavi edildiler. Elli sekiz hastanın yarası deri grefti ile iki hastanın yarası lokal flepler ile onarıldı. Hiçbir hastada serbest flebe gerek olmadı.

Sonuç: NBT ile yüksek enerjili travma sonucu ekstremitelerde oluşan yaralar basit cerrahi teknikler ile kapatılabilmekte, hastalar serbest doku transferinin komplikasyonlarından korunabilmekte, hem de çok daha az maliyetle tedavi sağlanabilmektedir.

Anahtar Sözcükler: Yaralar, negatif basınçlı terapi, ekstremite, travma

\section{Introduction}

High-energy trauma to the extremities that lead to open fractures with major soft tissue losses is frequent, especially in young adults. In extremity injuries caused by high energy trauma, it is necessary to remove the dead tissue from the site and properly close the soft tissue in order to protect the affected extremity from amputation. Soft tissue defects in the extremities are caused by the effects of trauma and posttraumatic debridements $(1,2)$. The surgical method which will be used in closing the defect is decided according to the size of the wound, whether there are tissues such as bone or tendon at the
Address for Correspondence/Yazışma Adresi: Erkan Orhan

Namık Kemal University Faculty of Medicine, Department of Plastic Surgery, Tekirdağ, Turkey

Phone: +90 5325004192 E-mail: eorhan@yahoo.com ORCID ID: orcid.org/0000-0001-6532-5840

Received/Geliş Tarihi: 17 January 2018 Accepted/Kabul Tarihi: 10 March 2018
${ }^{-}$Copyright 2018 by The Medical Bulletin of University of Health Sciences Haseki Training and Research Hospital

The Medical Bulletin of Haseki published by Galenos Yayınevi.

Telif Hakkı 2018 Sağlık Bilimleri Üniversitesi Haseki Eğitim ve Araştırma Hastanesi Haseki Tıp Bülteni, Galenos Yayınevi tarafından basıımıştı. 
base of the wound, and exposure of the implants used in stabilizing the bone. Skin grafts, local myocutaneous and fasciocutaneous flaps, distant flaps, and free flaps can be used in closing defects, which cannot be closed primarily. Although reconstruction with skin grafts is the easiest surgical method, it requires a well-vascularized recipient bed and cannot be performed if there is exposed bone, cartilage, tendon or surgical implants. It is mandatory to use flaps in these cases (1). Free tissue transfer is necessary if the soft tissue loss is too large to be closed with local flap and sometimes more than one flap may be required in wide defects. As the size and depth of the wound increases, the need for more extensive surgeries arises; and as a result of these major surgeries, donorsite morbidity, frequency of complications, and length of hospital stay increases $(1,3)$.

Negative pressure terapy (NPT) systems have been used frequently as a non-surgical method in wound treatment for the last 20 years. NPT, which has been developed for closing large, chronic, and infected wounds, has also started to be used in traumatic wounds. Thanks to these systems, it is possible to close the wounds, if not at least wound closure with simpler surgical techniques can be provided $(4,5)$.

In this study, we present patients whose extremity defects caused by high energy trauma were treated with NPT.

\section{Methods}

This research was conducted in compliance with all ethical standards given in the Helsinki Declaration of 1975 as revised in 2008 and was approved by Clinical Research Ethics Committee of Ankara Numune Training and Research Hospital (2009/21). Written informed consent was obtained from all individual participants included in the study. Patients, who had developed soft tissue defects with exposed bone and tendon in the upper and lower extremities due to high-energy trauma and were treated with NPT between November 2009 and June 2015, were included in the study. No exclusion criteria were used in the study. The patients with bone and joint injuries were treated by the department of orthopaedic surgery using appropriate methods. Surgical debridement was performed under anesthesia in the operating room environment and necrotic tissues were removed from the wound site in all patients. Debridements were repeated every two days in patients in whom adequate debridement was not achieved in the first time. NPT was initiated after the dead tissue was removed from the wound site. NPT was implemented using a vacuumassisted closure system (Kinetic Concepts, Inc, San Antonio, Texas, USA) in all patients. Polyurethane foam was cut according to the wound size and placed on the surface of the wound, so it would close the entire surface yet would not overflow it. The sponge was then dressed by an adhesive cover to form an airtight environment. A tube was placed in a small hole opened in the foam and the other end of the tube was connected to the device's collection container.

The patients underwent three sessions of NPT weekly during their stay, and it was adjusted so the foam was changed on mondays, wednesdays, and fridays. All patients underwent negative pressure of $125 \mathrm{mmHg}$. NPT was implemented continuously for the first three practices, and intermittently as active five minutes followed by passive two minutes in the continuing practices.

When NPT would be implemented on the exposed bones, holes were drilled in the bone cortex at $1 \mathrm{~cm}$ intervals during surgical debridement in order to ensure the formation of granulation tissue from the bone medulla as well.

\section{Statistical Analysis}

Data analysis was performed by using IBM SPSS Statistics version 17.0 (IBM Corporation, Armonk, NY, USA). The Kolmogorov-Smirnov test was used to assess whether the continuous variables were distributed normally or not. Levene's test was used for the evaluation of homogeneity of variances. Descriptive statistics for continuous variables were expressed as mean \pm standard deviation or median (minimum-maximum), where applicable. Numbers and percentages were used for categorical data. While the mean differences among groups were analyzed by OneWay ANOVA, otherwise, the Kruskal-Wallis test was applied for the comparisons of not normally distributed data. A p-value of less than 0.05 was considered statistically significant and when a $p$ value was statistically significant, post-hoc Tukey HSD or Conover's multiple comparison test were used to know which group differ from which others. Categorical data were evaluated by Pearson's chi-square test. Degrees of association between continuous variables were evaluated by Spearman's rank correlation analyses.

\section{Results}

The treatment was performed in a total of 63 patients (56 male, 7 female) with a mean age of 36.8 (3-73) years. $7.9 \%$ of the defects were on the forearm and elbow, $15.9 \%$ on the hand and wrist, $38.1 \%$ on the thigh and leg, $22.2 \%$ on the dorsum of the foot and ankle, and $15.9 \%$ on the sole of the foot. Thirty nine of the wounds were caused by traffic accidents, three were due to burn injury, 15 were because of work accidents, and six were related to a fall. The bone, tendon, or plaque/screw used in bone stabilization was exposed in defects in all patients. For all defects, the average of the defect areas was estimated at $60 \mathrm{~cm}^{2}$ (4-800); an average of nine sessions (3-24) of NBT was performed and the average length of hospital stay was 26 (10-65) days (Table 1). Wound care dressing was done at the bedside in all patients and no pain was endured. No problem occurred in any of the patients including four pediatric patients aged three-nine years. 
The average size of the defect area was estimated at $45 \mathrm{~cm}^{2}$ (4-90) on the forearm and elbow, $30 \mathrm{~cm}^{2}$ (12-60) on the hand and wrist, $110 \mathrm{~cm}^{2}$ (24-800) on the thigh and leg, $55 \mathrm{~cm}^{2}$ (24-100) on the dorsum of the foot and ankle, and $45 \mathrm{~cm}^{2}$ (24-80) on the sole of the foot. The defect area on the thigh and leg was statistically significantly larger than on other sites $(p<0.001)$ (Table 2) (Figure 1).

An average of eight sessions (4-15) of NPT was performed for the hand and wrist defects, five sessions (37) for the forearm and elbow defects, 9.5 sessions (5-24) for the thigh and leg defects, eight sessions (4-11) for the

\begin{tabular}{|c|c|}
\hline Number of cases, $n$ & 63 \\
\hline Age (years), mean \pm SD & $36.8 \pm 17.1$ \\
\hline Range of age (years) & $3-73$ \\
\hline \multicolumn{2}{|l|}{ Gender, n (\%) } \\
\hline Male & $56(88.9)$ \\
\hline Female & $7(11.1)$ \\
\hline \multicolumn{2}{|l|}{ Defect level } \\
\hline Hand and wrist, $\mathrm{n}(\%)$ & $10(15.9)$ \\
\hline Forearm and elbow, n (\%) & $5(7.9)$ \\
\hline Thigh and leg, $n(\%)$ & $24(38.1)$ \\
\hline Dorsum of the foot and ankle, $\mathrm{n}(\%)$ & $14(22.2)$ \\
\hline Sole of the foot, $n$ (\%) & $10(15.9)$ \\
\hline Defect size, $\mathrm{cm}^{2}$ (range) & $60(4-800)$ \\
\hline Number of NPT session, $\mathrm{n}$ (range) & $9(3-24)$ \\
\hline Hospitalization (days), n (range) & $26(10-65)$ \\
\hline \multicolumn{2}{|l|}{ Type of reconstruction, $n$ (\%) } \\
\hline Flap & $2(3.2)$ \\
\hline Secondary healing & $3(4.8)$ \\
\hline Skin graft & $58(92.1)$ \\
\hline
\end{tabular}

defects of dorsum of the foot and ankle, and 11 sessions (4-13) were performed for the defects of the sole of the foot. The average number of NBT session for the forearm and elbow was statistically significantly lower than for the other sites $(p<0.001)$ (Table 2) (Figure 2).

The mean length of hospital stay was 23.5 days (1442 ) in patients who had hand and wrist defects, 15 days (10-20) in those with forearm and elbow defects, 29 days (17-65) - thigh and leg defects. 20.5 days (13-38) - foot and ankle defects, and 32 days (16-36) in those with defects on the sole of the foot. The mean length of hospital stay in patients with forearm and elbow defects was statistically significantly lower than in those with defects in the other sites $(p<0.001)$ (Table 2) (Figure 3).

After NPT, one thigh defect and two dorsum of foot defects closed secondarily, one hand and wrist defect and one thigh and leg defect were reconstructed with local flaps and the remaining 58 defects were reconstructed with partial thickness skin grafts.

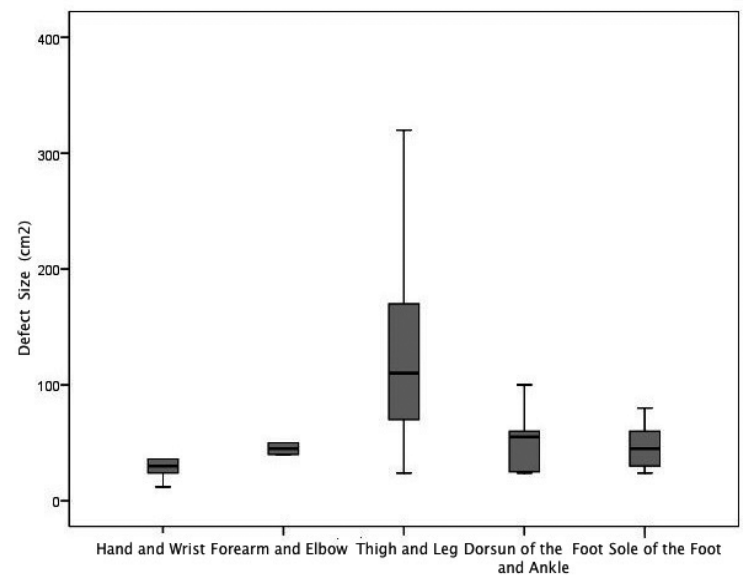

Figure 1. Distributions of defects levels according to defects size

Table 2. Demographical and clinical characteristics of cases

\begin{tabular}{|c|c|c|c|c|c|c|}
\hline & Hand and wrist & $\begin{array}{l}\text { Forearm and } \\
\text { elbow }\end{array}$ & $\begin{array}{l}\text { Thigh and } \\
\text { leg }\end{array}$ & $\begin{array}{l}\text { Dorsum of the } \\
\text { foot and ankle }\end{array}$ & $\begin{array}{l}\text { Sole of the } \\
\text { foot }\end{array}$ & $\mathrm{p}$-value \\
\hline Age (years), mean \pm SD & $33.9 \pm 18.3^{\mathrm{A}}$ & $30.4 \pm 4.5^{\mathrm{A}}$ & $36.7 \pm 14.0^{A}$ & $25.5 \pm 15.4^{\mathrm{A}}$ & $58.8 \pm 7.5^{B}$ & $<0.00^{+}$ \\
\hline Gender, n (\%) & - & - & - & - & - & $0.080^{\ddagger}$ \\
\hline Male & $9(90.0)$ & $5(100.0)$ & $18(75.0)$ & $14(100.0)$ & $10(100.0)$ & \\
\hline Female & $1(10.0)$ & $0(0.0)$ & $6(25.0)$ & $0(0.0)$ & $0(0.0)$ & \\
\hline Defect size, $\mathrm{cm}^{2}$ (range) & $30(12-60)^{A}$ & $45(4-90)^{A}$ & $110(24-800)^{\mathrm{B}}$ & $55(24-100)^{\mathrm{A}}$ & $45(24-80)^{A}$ & $<0.001^{\pi}$ \\
\hline Number of NPT session, $\mathrm{n}(\%)$ & $8(4-15)^{A}$ & $5(3-7)^{\mathrm{B}}$ & $9.5(5-24)^{\mathrm{A}}$ & $8(4-11)^{A}$ & $11(4-13)^{A}$ & $0.025^{\pi}$ \\
\hline Hospitalization, days (range) & $23.5(14-42)^{A}$ & $15(10-20)^{\mathrm{B}}$ & $29(17-65)^{\mathrm{A}}$ & $20.5(13-38)^{A}$ & $32(16-36)^{A}$ & $0.010^{\pi}$ \\
\hline \multicolumn{7}{|l|}{ Type of reconstruction } \\
\hline Flap, n (\%) & $1(10.0)$ & $0(0.0)$ & $1(4.2)$ & $0(0.0)$ & $0(0.0)$ & $0.637^{\ddagger}$ \\
\hline Secondary healing, $\mathrm{n}(\%)$ & $0(0.0)$ & $0(0.0)$ & $1(4.2)$ & $2(14.3)$ & $0(0.0)$ & $0.397^{\ddagger}$ \\
\hline Skin graft, n (\%) & $9(90.0)$ & $5(100.0)$ & $22(91.6)$ & $12(85.7)$ & $10(100.0)$ & $0.712^{\ddagger}$ \\
\hline
\end{tabular}




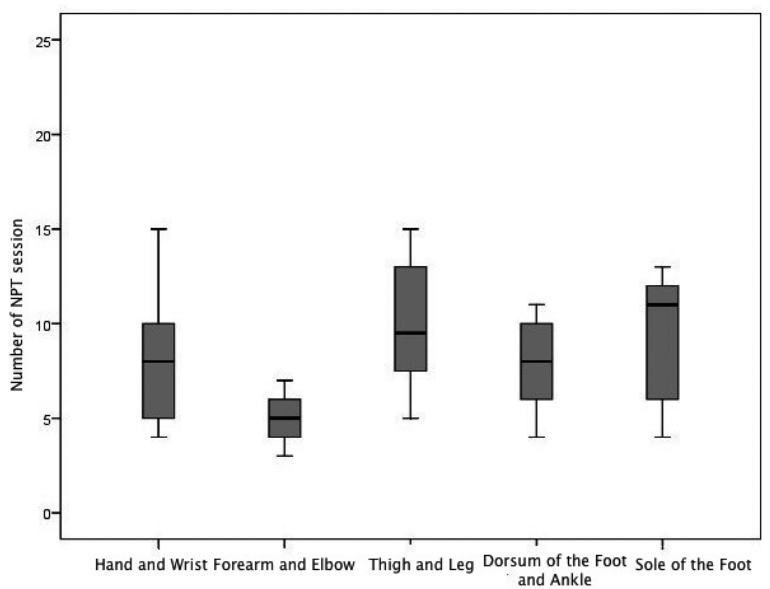

Figure 2. Distributions of defects levels according to number of negative pressure therapy sessions NPT: Negative pressure therapy

\begin{tabular}{|l|l|l|l|}
\hline \multicolumn{4}{|l|}{$\begin{array}{l}\text { Table 3. The results of correlation analyses between defect } \\
\text { size and number of negative pressure therapy session }\end{array}$} \\
\hline & $\mathbf{n}$ & $\begin{array}{l}\text { Coefficient of } \\
\text { correlation }\end{array}$ & $\mathbf{P}$ \\
\hline Hand and wrist & 10 & 0.928 & $<0.001$ \\
\hline Forearm and elbow & 5 & 0.100 & 0.873 \\
\hline Thigh and leg & 24 & 0.422 & 0.040 \\
\hline $\begin{array}{l}\text { Dorsum of the foot and } \\
\text { ankle }\end{array}$ & 14 & 0.285 & 0.324 \\
\hline Sole of the foot & 10 & 0.794 & 0.006 \\
\hline Overall & 63 & 0.519 & $<0.001$ \\
\hline
\end{tabular}

None of the patients required free tissue flaps. There was a graft loss of $30 \%$ in a 73 -year-old diabetic patient whose defect was located on the dorsum of the hand and was reconstructed using a graft and this defect recovered secondarily. No complications occurred in other than this case.

After making correlation analyses between defect size and number of NPT session in all cases, there was a statistically significant correlation between increasing defect size and number of NBT session $(r=0.519, p<0.001)$, but when only defects on the forearm and elbow and defects on the dorsum of the foot and ankle were considered, there was no statistically significant correlation between defect size and number of NBT session $(r=0.100$, $p=0.873$ and $r=0.285, p=0.324$, respectively) (Table 3 ).

\section{Discussion}

NBT was developed for treating large, chronic wounds and was mainly developed to turn the wound beds of chronic, wide, and infected wounds into ones suitable for reconstruction $(4,6)$. NPT, which is administered after appropriate surgical debridement of such chronic wounds, increases granulation tissue formation and thus, makes it possible to close the wound with less aggressive surgical procedures $(4,6,7)$. It is also an alternative treatment option in patients not suitable for surgical procedures and those with small defects (6).

The positive effect of NPT on wound healing is due to multiple factors. With NPT, excess wound exudate, which contains factors that inhibit fibroblasts, endothelial cells, and keratinocytes are removed from the site $(4,6)$. Also, the edema surrounding the wound decreases with NPT and with this decrease, the blood vessels around the wound dilate and the blood flow to the wound increases. Herscovici et al. (1) determined that over 500 cc of fluid is taken from the tissues in the first 24 hours in NPT applications after high-energy trauma. The increase
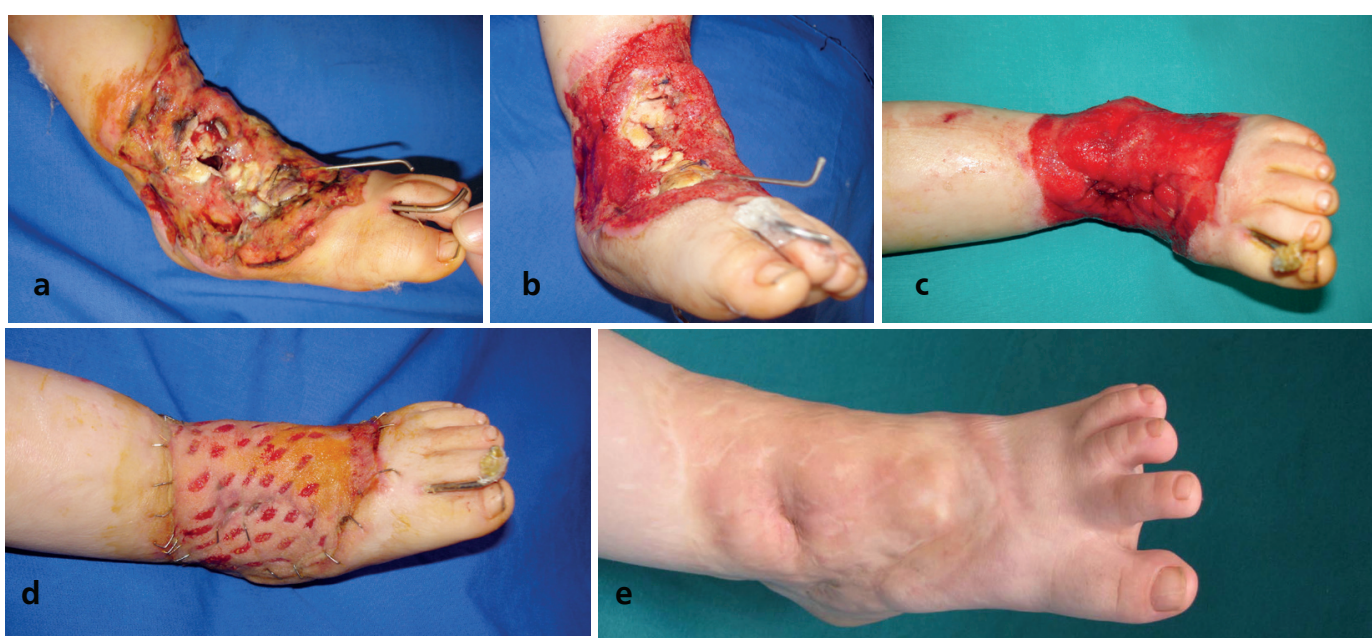

Figure 3. (a) Three years old boy, the wound located on the dorsum of the left foot and ankle as a result of a traffic accident. View of a $10 \times 5 \mathrm{~cm}$ defect with exposed tendon on the base of the wound. (b) View of the defect after debridement and bone stabilization. (c) The surface of the tendons were completely covered by granulation tissue. (d) The defect was reconstructed with skin grafts. (e) View of the defect in the second year postoperative. There were no complications 
in blood flow to the wound site helps the granulation tissue form more rapidly. In a randomized prospective study, NPT and wet dressing were compared in terms of granulation tissue formation and it was shown that granulation tissue formed much faster with NPT (2). Also, NPT prevent colonization of anaerobic bacteria and decrease bacterial load of the wound. It has been shown that with NPT, the bacterial load reduced from 107 to 103 in four-five days $(1,4,5)$. Another factor is that NPT transmits an equal amount of mechanical force against the tissue surrounding the wound. It was shown for the first time in 1911 that mechanical force stimulates tissue angiogenesis and growth. Clinically used techniques, such as tissue expanders and the llizarov techniques, both apply mechanical force. With NPT, the mechanical force applied on the tissues surrounding the wound ensures the surrounding tissue to migrate towards the center of the defect, and as a result, the wound decrease in size $(1,8,9)$.

Different surgical techniques have been identified for closure of large soft tissue defects in extremities, especially due to high-energy trauma, such as skin grafts, local fasciocutaneous-musculocutaneous flaps, and free flaps (10). Skin grafting is a simple surgical procedure and the fact that grafts can be obtained in large amounts allows them to be used when repairing large defects and therefore makes them the most preferred method, however, the success depends on the vascularity of the recipient bed. Skin grafts cannot be applied on bone, cartilage, tendon or surgical implants (11). Local flaps are needed in such cases. As for defects which are too large to be repaired locally, free flaps are needed. Although successful results can be achieved with the use of free flaps, these surgeries cause problems such as sacrificing major arteries, prolonged operative time, and donor site morbidity. They also require special equipment and surgical skills $(1,11)$. There is a $5 \%$ failure rate after free flap surgery and this rate increases especially in defects located at the tibial region. There is a $7 \%$ risk for amputation of the lower extremity after free flap surgery (12).

Various studies have been conducted regarding the use NPT for reconstruction of extremity defects due to high energy trauma, without the need for free flaps. In a prospective study conducted by Mullner et al. (13) in 1997, it was reported that lower extremity defects due to high energy trauma in 12 patients, in which the bone and plates were exposed, recovered within an average of 16 days of NPT treatment following rigid bone stabilization. In their series including 75 patients, DeFranzo et al. (8) reported that lower extremity wounds with exposed bone and tendons were the result of trauma in 49 patients without osteomyelitis of the lower extremity; the patients were treated with NPT after debridement and a success rate of $95 \%$ was achieved. The wounds were closed primarily in 12 patients, skin grafts were used in 58 , and local flaps were used in five patients. None of the patients required free flap surgery. There were no complications in the patients who were followed up for a period of six months-six years. As for a series including 96 patients, NPT treatment was administered in 96 patients who had defects on the foot or ankle due to trauma with exposed tendon, bone, or implants. In 92 patients, the wounds could be closed with an average of six weeks of topical negative pressure (TNP) treatment after the injury, without the need for free flaps (14). As for our study, NPT treatment was administered in 63 patients who had an average of $60 \mathrm{~cm}^{2}$ defects with exposed bone, tendon, and implants in different locations of the upper and lower extremities. The defects were reconstructed with grafts in 58 of the 63 patients after an average of 26 days hospital stay and nine sessions of TNP treatment and none of the patients required free flaps.

In our study, the relationship between defect size and NBT session required was directly proportional in all regions except forearm and elbow and dorsum of the foot and ankle. For defects on those levels, fewer NBT sessions and shorter hospital stay were needed according to defects size.

TNP is generally accepted as a reliable method of treatment. The most important complication of the treatment is the pain endured while changing the sponges (15). The pain is intermittent and is particularly due to the negative pressure itself, and the pain can mostly be eliminated by lowering the pressure. There were no complications, particularly pain, encountered during the sponge changes or treatment process in our study. Theoretically, NPT can cause arterial injury and major bleeding, thus, application of the sponge directly on the vessels is contraindicated. In their study including 75 patients, DeFronzo et al. (8) reported that none of the patients who were treated with NPT had bleeding. However, White et al. (16), reported a case of anterior tibial artery injury associated with NPT 22 days after treatment. Excessive granulation tissue formation may also cause bleeding especially in children and young adults $(4,5,17)$. In our study, none of the patients, including the pediatric patients, had bleeding.

Cases of bacterial infections and toxic shock syndrome associated with NPT treatment have been reported in the literature (14). The anaerobic environment caused by NPT is particularly favorable for the growth of anaerobic bacteria $(18,19)$. In contrast to these publications, many clinical trials have shown that NPT reduced bacterial load $(20,21)$.

Four of the patients treated with NPT in our study were pediatric patients aged three-nine years and there was no problem during the treatment period. Similarly, Mooney et al. (7) used TNP treatment for soft tissue defects in 27 children, 20 of whom had defects on the extremities, and stated that the children tolerated the treatment very well.

In a study by Herscovici et al. (1), NPT was compared with wet dressings and free tissue transfers in terms 
of cost. When the total costs of dressing materials and nursing were included, the daily cost of wet dressing was estimated to be 100 dollars, the daily cost of NPT was 103 dollars; whereas for free tissue transfer, only the cost of surgery was estimated to be 6000 dollars. According to this calculation, NPT is not more expensive than wet dressing and it also has advantages other than its positive effect on wound healing such as allowing ambulation of patients during the treatment and requiring only a few dressing changes. Sixty days of NPT treatment is required for the cost of NPT to equal the cost for free tissue transfer, and according to our study, the average length of hospital stay was 26 days.

\section{Study Limitations}

The fact that NBT and early conventional flap coverage were not compared and a relatively small number of cases for such an in homogenous group were the limitations of this study.

\section{Conclusion}

With the use of NPT using simpler methods, particularly skin grafts, in the treatment of acute extremity wounds due to high-energy trauma, it has been possible to close defects without the need for free flaps. Thus, the patients are protected from the complications of free tissue transfer, and also treatment is possible at much lower cost.

\section{Authorship Contributions}

Surgical and Medical Practices: E.O., B.E. Concept: E.O., B.E. Design: E.O., B.E. Data Collection or Processing: E.O. Analysis or Interpretation: E.O. Literature Search: E.O. Writing: E.O.

Conflict of Interest: No conflict of interest was declared by the authors.

Financial Disclosure: The authors declared that this study received no financial support.

\section{References}

1. Herscovici D Jr, Sanders RW, Scaduto JM, Infante A, DiPasquale T. Vacuum-assisted wound closure (VAC therapy) for the management of patients with high-energy soft tissue injuries. J Orthop Trauma 2003;17:683-8.

2. Sinha K, Chauhan VD, Maheshwari R, Chauhan N, Rajan M, Agrawal A. Vacuum Assisted Closure Therapy versus Standard Wound Therapy for Open Musculoskeletal Injuries. Adv Orthop 2013;2013:245940.

3. Paro J, Chiou G, Sen SK. Comparing Muscle and Fasciocutaneous Free Flaps in Lower Extremity Reconstruction-Does It Matter? Ann Plast Surg 2016;76(Suppl 3):S213-5.

4. Novak A, Khan WS, Palmer J. The evidence-based principles of negative pressure wound therapy in trauma \& orthopedics. Open Orthop J 2014;27:168-77.

5. Raj M, Gill SP, Sheopaltan SK, et al. Evaluation of Vacuum Assisted Closure Therapy for Soft Tissue Injury in Open Musculoskeletal Trauma. J Clin Diagn Res 2016;10:RC5-RC8.
6. Argenta LC, Morykwas MJ. Vacuum-assisted closure: a new method for wound control and treatment. Clinical experience. Ann Plast Surg 1997;38:563-76.

7. Mooney JF III, Argenta LC, Marks MW, Morykwas MJ, DeFranzp AJ. Treatment of soft tissue defects in pediatric patients using the V.A.C. system. Clin Orthop Relat Res 2000;376:26-31.

8. DeFranzo AJ, Argenta LC, Marks MW, et al. The use of vacuum-assisted closure therapy for the treatment of lowerextremity wounds with exposed bone. Plast Reconstr Surg 2001;108:1184-91.

9. Olenius M, Dalsgaard CJ, Wickman M. Mitotic activity in expanded human skin. Plast Reconstr Surg 1993;91:213-6.

10. Sabino JM, Slater J, Valerio IL. Plastic Surgery Challenges in War Wounded I: Flap-Based Extremity Reconstruction. Adv Wound Care (New Rochelle) 2016;5:403-11.

11. Eser C, Kesiktaş E, Gencel E, Aslaner EE, Yavuz M. An alternative method to free flap for distal leg and foot defects due to electrical burn injury: distally based cross-leg sural flap. Ulus Travma Acil Cerrahi Dergv 2016;22:46-51.

12. Fischer JP, Wink JD, Nelson JA, et al. A retrospective review of outcomes and flap selection in free tissue transfers for complex lower extremity reconstruction. J Reconstr Microsurg 2013;29:407-16.

13. Mullner T, Mrkonjic L, Kwasny O, Vecsei $V$. The use of negative pressure to promote the healing of tissue defects: a clinical trial using the vacuum sealing technique. Br J Plast Surg 1997;50:194-9.

14. Bovill $E$, Banwell PE, Teot $L$, et al. Topical negative pressure wound therapy: a review of its role and guidelines for its use in the management of acute wounds. Int Wound J 2008; 5:511-29.

15. Wagstaff MJ, Driver S, Coghlan P, Greenwood JE. A randomized, controlled trial of negative pressure wound therapy of pressure ulcers via a novel polyurethane foam. Wound Repair Regen 2014;22:205-11.

16. White RA, Miki RA, Kazmier P, Anglen JO. Vacuum-assisted closure complicated by erosion and hemorrhage of the anterior tibial artery. J Orthop Trauma 2005;19:56-9.

17. Fuchs $U$, Zittermann A, Stuettgen B, Groening A, Minami K, Koerfer R. Clinical outcome of patients with deep sternal wound infection managed by vacuum-assisted closure compared to conventional therapy with open packing: a retrospective analysis. Ann Thorac Surg 2005;79:526-31.

18. Chester DL, Waters R. Adverse alteration of wound flora with topical negative-pressure therapy: a case report. $\mathrm{Br} J$ Plast Surg 2002;55:510-1.

19. Weed T, Ratliff C, Drake DB. Quantifying bacterial bioburden during negative pressure wound therapy: does the wound VAC enhance bacterial clearance? Ann Plast Surg 2004;52:276-9.

20. Pinocy J, Albes JM, Wicke C, Ruck P, Ziemer G. Treatment of periprosthetic soft tissue infection of the groin following vascular surgical procedures by means of a polyvinyl alcohol-vacuum sponge system. Wound Repair Regen 2003;1182:104-9.

21. Deva AK, Buckland GH, Fisher E, et al. Topical negative pressure in wound management. Med J Aust 2000;173:128-31. 